\title{
PII S0016-7037(99)00227-6
}

\section{Effect of hydroxamate siderophores on Fe release and $\mathrm{Pb}(\mathrm{II})$ adsorption by goethite}

\author{
Stephan M. Kraemer, ${ }^{1} *$ Sing-Foong Cheah, ${ }^{1}$ Rita Zapf, ${ }^{1, \dagger}$ Jide Xu,${ }^{2}$ Kenneth N. Raymond, ${ }^{2}$ and Garrison Sposito \\ ${ }^{1}$ Division of Ecosystem Sciences, University of California, Berkeley, California 94720-3110, USA \\ ${ }^{2}$ Department of Chemistry, University of California, Berkeley, California 94720-1460, USA
}

(Received October 15, 1998; accepted in revised form April 29, 1999)

\begin{abstract}
Hydroxamate siderophores are biologically-synthesized, Fe(III)-specific ligands which are common in soil environments. In this paper, we report an investigation of their adsorption by the iron oxyhydroxide, goethite; their influence on goethite dissolution kinetics; and their ability to affect $\mathrm{Pb}$ (II) adsorption by the goethite surface. The siderophores used were desferrioxamine B (DFO-B), a fungal siderophore, and desferrioxamine $\mathrm{D}_{1}$, an acetyl derivative of DFO-B (DFO-D1). Siderophore adsorption isotherms yielded maximum surface concentrations of 1.5 (DFO-B) or 3.5 (DFO-D1) $\mu \mathrm{mol} / \mathrm{g}$ at $\mathrm{pH} 6.6$, whereas adsorption envelopes showed either cation-like (DFO-B) or ligand-like (DFO-D1) behavior. Above pH 8, the adsorbed concentrations of both siderophores were similar. The dissolution rate of goethite in the presence of $240 \mu \mathrm{M}$ DFO-B or DFO-D1 was 0.02 or $0.17 \mu \mathrm{mol} / \mathrm{g} \mathrm{hr}$, respectively. Comparison of these results with related literature data on the reactions between goethite and acetohydroxamic acid, a monohydroxamate ligand, suggested that the three hydroxamate groups in DFO-D1 coordinate to Fe(III) surface sites relatively independently. The results also demonstrated a significant depleting effect of $240 \mu \mathrm{M}$ DFO-B or DFO-D1 on $\mathrm{Pb}$ (II) adsorption by goethite at $\mathrm{pH}>6.5$, but there was no effect of adsorbed $\mathrm{Pb}$ (II) on the goethite dissolution rate. Copyright (C) 1999 Elsevier Science Ltd
\end{abstract}

\section{INTRODUCTION}

Siderophores are Fe(III)-specific ligands of low relative molecular mass that are synthesized by fungi and bacteria as a response to iron stress (Powell et al., 1982; Telford and Raymond, 1996). Fungi produce mainly trihydroxamate siderophores, a typical example being desferrioxamine B (Powell et al., 1982; Crumbliss, 1991; Albrecht-Gary and Crumbliss, 1998), in which three hydroxamate groups (Fig. 1) contribute to hexadentate ligation of $\mathrm{Fe}^{3+}$ in 5 membered rings with an exceptional combination of high specificity and stability (1:1 complex formation constant of $10^{31}$ (Telford and Raymond, 1996), as compared to $10^{25}$ for Fe-EDTA). These siderophores are common in soil environments (Powell et al., 1982; Crowley and Gries, 1994). Their soil solution concentrations increase significantly with organic matter content and with proximity to living plant roots (Powell et al., 1982; Crowley et al., 1987).

Watteau and Berthelin (1994) demonstrated the efficacy of trihydroxamate siderophores as promoters of $\mathrm{Fe}(\mathrm{III})$-mineral dissolution by incubating samples of synthetic goethite $(\alpha-\mathrm{FeOOH})$ over a month long period at $24^{\circ} \mathrm{C}$ with Suillus granulatus, an ectomychorrhizal fungus, and with an abiotic 126 ( $\mu \mathrm{M}$ solution of desferrioxamine B. Significant quantities of Fe were mobilized by the fungi in close correspondence with their production of siderophores. Goethite was dissolved very rapidly at $\mathrm{pH} 3$ by desferrioxamine $\mathrm{B}(<2$ days) at a rate that was about an order of magnitude greater than dissolution at $\mathrm{pH}$ 3 promoted by $\mathrm{H}^{+}$or by common aliphatic acids. Noting that the Fe solubilized after 28 days accounted for only about $8 \%$ of the complexing capacity of the added desferrioxamine B,

*Address reprint requests to S. M. Kraemer, University of California, Berkeley, 235 Hilgard Hall, Berkely, CA 94720, USA (skraemer@ nature.berkeley.edu).

Present address: Riedelsberger Weg 42, D-95448 Bayreuth, Germany
Watteau and Berthelin (1994) suggested that further research was needed on the accessibility of this siderophore to the goethite surface.

Holmén and Casey $(1996 ; 1998)$ and Holmén et al. (1997) have explored the mechanisms of hydroxamate-promoted dissolution of goethite in studies utilizing a model compound, acetohydroxamic acid (Fig. 1), which is a small ligand possessing a single hydroxamate functional group. They concluded from dissolution kinetics data, as well as from FTIR spectroscopic measurements, that adsorbed acetohydroxamic acid forms a surface chelate with exposed $\mathrm{Fe}^{3+}$ by an associative ligand exchange mechanism (Stumm et al., 1990; Holmén and Casey, 1996). The metal-organic bonding in the surface chelate formed with this bidentate ligand is very similar to that in the soluble Fe(III) chelate, which is a five-membered ring including the N-O bond (Holmén et al., 1997). No evidence for multinuclear surface complexes or unidentate ligation under the conditions of their experiments was found by Holmén et al. (1997). Holmén and Casey (1996; 1998) noted also that the adsorption envelope (graph of amount adsorbed versus $\mathrm{pH}$ ) for acetohydroxamic acid on goethite was ligand-like (Stumm, 1992), as expected. The rate of goethite dissolution was much less than the rate of surface complex formation, leading therefore to the well-known linear correlation between the dissolution rate coefficient and adsorbed ligand concentration (Stumm et al., 1990).

In this paper, we report the first adsorption and dissolution experiments involving goethite and the fungal siderophore, desferrioxamine B. One objective of our study was to provide basic information about the surface concentrations of this trihydroxamate siderophore and its influence on goethite dissolution kinetics. Adsorption and dissolution experiments also were performed with an acetyl derivative of desferrioxamine B, namely desferrioxamine $\mathrm{D}_{1}$, in which the proton on the terminal amine group in desferrioxamine B is replaced by an acetyl 
<smiles>[2H]N([2H])CN(O)C(=O)CC(=O)NCCN(O)C(=O)CC(=O)NCCN(O)C(C)=O</smiles>

Desferrioxamine B: $\quad \mathrm{R}=\mathrm{H}$

Desferrioxamine $D_{1}: \quad R=$
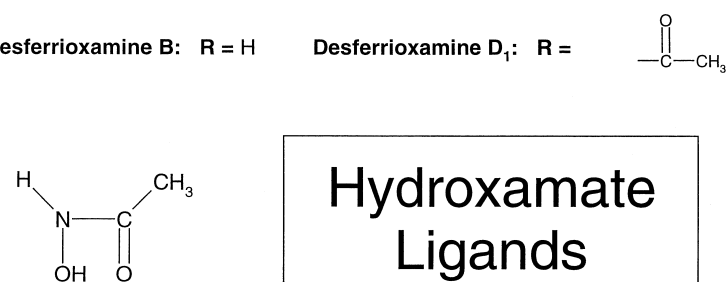

\section{Hydroxamate Ligands}

Acetohydroxamic acid

Fig. 1. Molecular structure of desferrioxamine $B$ and $D_{1}$. The three hydroxamate groups are at the bottom of the structure. The small ligand, acetohydroxamic acid, shown at the lower left, contains only a single hydroxamate group.

group (Fig. 1), thereby removing a source of positive charge on the siderophore. Desferrioxamine B is a cationic species at $\mathrm{pH}<8$ (Borgias et al., 1989). Desferrioxamine $\mathrm{D}_{1}$ is excreted by the actinomycete Streptomyces pilosus (Bickel et al., 1960; van der Helm et al., 1987). It was used in our experiments to provide additional data for extrapolating from the behavior of the neutral acetohydroxamic acid (Holmén et al., 1997) to that of the positively-charged desferrioxamine B.

Although the stability constants of complexes between siderophores and other trace metals are not as high as that with $\mathrm{Fe}(\mathrm{III})$, they are not insignificant (Hernlem et al., 1995). These relatively high stability constants, together with the common occurrence of siderophores in soil environments, suggest that siderophores could potentially have impact on the transport and mobility of trace metals other than Fe(III). To explore this possibility, some of our experiments included adsorbed $\mathrm{Pb}$ (II) as a typical hazardous trace metal whose surface complexation reactions with goethite have been investigated extensively (e.g., Müller and Sigg, 1992; Rodda et al., 1993; Gunneriusson et al., 1994; Bargar et al., 1997), and for which formation constants of $\mathrm{Pb}$ (II)-desferrioxamine $\mathrm{B}$ complexes in aqueous solution are available (Hernlem et al., 1995). Our new results, pertaining to the effect of a hydroxamate siderophore on adsorbed $\mathrm{Pb}$ (II), are relevant to hazardous metal waste recovery and remediation in soils (Brainard et al., 1992).

\section{EXPERIMENTAL}

\subsection{Materials}

Goethite was synthesized by the method of Schwertmann and Cornell (1991) and freeze dried. Powder X-ray diffraction (Siemens) confirmed that the synthesized solid was goethite. Its specific surface area was $35 \pm 3 \mathrm{~m}^{2} / \mathrm{g}$, as determined by the static BET method.

The sample of desferrioxamine B (DFO-B) used was produced by Ciba-Geigy (Desferal ${ }^{\circledR}$ ) and received as a gift from the Salutar Corporation. The sample of desferrioxamine D1 (DFO-D1) used was prepared from DFO-B by per-acetylation in methanol. Hydrolysis of the hydroxamate esters of the per-acetylated DFO-B with ammonia gave the desired DFO-D1 product in good yield. The mesylate salt of DFO-B $(6.58 \mathrm{~g}$ or $10 \mathrm{mmol})$ and sodium acetate $(3.28 \mathrm{~g}$ or $40 \mathrm{mmol})$ were dissolved in $100 \mathrm{~mL}$ methanol. Acetic anydride $(57 \mathrm{~mL}, 50 \mathrm{mmol})$ was added slowly to this ice-cooled solution. The mixture was stirred for $8 \mathrm{hr}$ under $\mathrm{N}_{2}$ and the volatile products were removed under vacuum. A colorless thick oil of per-acetylated DFO-B resulted and was used directly for the next step of the preparation reaction. The crude peracetylated DFO-B was dissolved in methanol $(40 \mathrm{~mL})$ and diluted with diethyl ether $(150 \mathrm{~mL})$. After cooling at $-20^{\circ} \mathrm{C}$ for $4 \mathrm{hr}$, the solution was filtered to remove insoluble material. The filtrate was saturated with gaseous ammonia and $N$-DFO-D1 was precipitated as a white solid, which was then washed with cold water (m.p. (uncorrected) $\left.180-181^{\circ} \mathrm{C}\right)$. The product yield was $4.5 \mathrm{~g}(7.46 \mathrm{mmol}$, or $74.6 \%)$. A $500 \mathrm{MHz}$ 1H NMR spectrum obtained on a Bruker AMX-500 spectrometer confirmed the composition and purity. Product analysis found calculated (measured) concentrations of $\mathrm{C}_{27} \mathrm{H}_{50} \mathrm{~N}_{6} \mathrm{O}_{9}$ to be $53.82 \%$ $(53.55 \%), 8.30 \%$ (8.40\%), $13.95(13.97 \%)$.

Solutions containing desferrioxamine B mesylate, desferrioxamine $\mathrm{D}_{1}$, Pb ICP standard solution (Ultra Scientific), Fe ICP standard solution (Ultra Scientific), Na perchlorate (GFS, ACS grade), HEPES buffer [4-(2-hydroxyethyl)-1-piperazineethanesulfonic acid] (Sigma, Ultra), MOPS buffer (4-morpholinepropanesulfonic acid; Boehringer, reagent grade), Fe (III) perchlorate hexahydrate (GFS, ACS grade), perchloric acid (Fisher, Optima) were prepared with high-purity $18 \mathrm{M} \Omega$ $\mathrm{cm}^{-1}$ water (Milli-Q Plus, Millipore).

\subsection{Analytical Methods}

The concentrations of DFO-B and DFO-D1 were measured with a Shimadzu UV-160 spectrophotometer at $463.2 \mathrm{~nm}$ as the siderophore complex in the presence of excess Fe. To prevent precipitation of Fe hydroxide, the $\mathrm{pH}$ value was adjusted to 1.5 by adding a predetermined volume of perchloric acid (dilution effects taken into account). After acidification, $\mathrm{Fe}(\mathrm{III})$ perchlorate solution was added to a final $\mathrm{Fe}$ concentration of $312 \mu \mathrm{M}$. Standards were prepared with siderophore concentrations of $20,40,80,120,160$, and $200 \mu \mathrm{M}$. Experimental samples were treated analogously to the standards. Iron and $\mathrm{Pb}$ were determined by ICP-AES (Thermo Jarrel-Ash) using emission lines at 238.2 and $220.3 \mathrm{~nm}$, respectively. Proton activity was measured with a $\mathrm{pH}$ meter (Orion $720 \mathrm{~A}$ ) and a Ross combination electrode calibrated with buffers at $\mathrm{pH} 4.0,7.0$, and 10 .

\subsection{Adsorption Measurements}

Lead adsorption edge measurements (amount adsorbed as a function of $\mathrm{pH}$ ) were performed in $0.01 \mathrm{M} \mathrm{NaClO}_{4}$ at a goethite concentration of $0.5 \mathrm{~g} / \mathrm{L}$, open to the atmosphere, and at ambient temperature. Some samples contained $5 \mathrm{mM}$ HEPES buffer. All samples were prepared in duplicate. Blanks (i.e., without goethite) were prepared over the $\mathrm{pH}$ range 3-9 to investigate $\mathrm{Pb}$ adsorption to container walls and filters, which was found to be $<3 \%$ of the initial $\mathrm{Pb}$ concentration. In the batch adsorption experiments, $15 \mathrm{mg}$ goethite and $25 \mathrm{~g}$ electrolyte (with or without buffer) were placed in $30 \mathrm{~mL}$ amber HDPE (high density poly (ethylene)) bottles. Lead and DFO-B stock solutions were added to final concentrations of $3.38 \mu \mathrm{M}$ and $240 \mu \mathrm{M}$, respectively (Table 1). Predetermined amounts of acid or base were then added to reach the desired $\mathrm{pH}$ value for each sample. The sample bottle was filled with electrolyte (buffer) to a final mass of $30 \mathrm{~g}$ and placed on a rotary shaker for $18 \mathrm{~h}$. The equilibrated samples were filtered using a $0.05 \mu \mathrm{m}$ mixed cellulose acetate syringe filter (MF-Millipore). The first $3 \mathrm{~mL}$ of the filtrate were discarded, then $10 \mathrm{~mL}$ were filtered and retained for $\mathrm{pH}$ determination. Finally, $10 \mathrm{~mL}$ were collected for $\mathrm{Pb}$ and $\mathrm{Fe}$ analysis and acidified using $60 \mu \mathrm{L}$ concentrated $\mathrm{HClO}_{4}$. The saturation state of all relevant solid $\mathrm{Pb}$ hydroxides and carbonates were calculated, and it was ascertained that all such solid phases were undersaturated under the experimental conditions of our study.

Adsorption isotherms and envelopes for DFO-B and DFO-D1 on goethite were measured at a high solids concentration of $13 \mathrm{~g} / \mathrm{L}$, because preliminary experiments indicated that the maximum DFO-B and DFO-D1 surface concentrations on goethite are relatively low. A disadvantage of this arrangement is a high rate of iron dissolution and the concomitant decrease of the free ligand concentration, particularly in the presence of DFO-D1. Therefore, the reaction times were short: only $50 \mathrm{~min}$ for DFO-D1 and $18 \mathrm{hr}$ for DFO-B. All adsorption measurements were performed in $0.01 \mathrm{M} \mathrm{NaClO}_{4}$ solution with $5 \mathrm{mM}$ 
Table 1. Experimental conditions for adsorption and dissolution studies.

\begin{tabular}{|c|c|c|c|c|c|}
\hline Experiment & $\begin{array}{l}\mathrm{Pb}_{\text {total }} \\
{[\mu \mathrm{M}]}\end{array}$ & $\begin{array}{c}\text { Ligand }_{\text {total }} \\
{[\mu \mathrm{M}]}\end{array}$ & $\mathrm{pH}$ & $\begin{array}{c}\text { Solid/liquid } \\
\text { [g/L] }\end{array}$ & $\begin{array}{c}\text { Reaction } \\
\text { time }\end{array}$ \\
\hline \multirow[t]{3}{*}{ Lead adsorption edge } & 3.48 & None & $3.5-7.5$ & 0.5 & $18 \mathrm{~h}$ \\
\hline & 3.48 & 240 (DFO-B) & $3.5-9.0$ & 0.5 & $18 \mathrm{~h}$ \\
\hline & 3.48 & 240 (DFO-D1) & $3.5-9.0$ & 0.5 & $18 \mathrm{~h}$ \\
\hline DFO-B adsorption isotherm & none & $15-150$ & 6.6 & 13 & $18 \mathrm{~h}$ \\
\hline DFO-B adsorption envelope & none & 150 & $3-9$ & 13 & $18 \mathrm{~h}$ \\
\hline DFO-D1 adsorption isotherm & none & $10-150$ & 6.6 & 13 & $50 \mathrm{~min}$ \\
\hline DFO-D1 adsorption envelope & none & 150 & $3.8-8.5$ & 13 & $50 \mathrm{~min}$ \\
\hline \multirow[t]{4}{*}{ Dissolution kinetics } & none & 240 (DFO-B) & 6.5 & 0.5 & 14.5 days \\
\hline & none & 240 (DFO-D1) & 6.5 & 0.5 & 14.5 days \\
\hline & 3.48 & 240 (DFO-B) & 6.5 & 0.5 & 14.5 days \\
\hline & 17.4 & 240 (DFO-B) & 6.5 & 0.5 & 14.5 days \\
\hline Dissolution kinetics (without pH buffer) & none & 240 (DFO-B) & 6.5 & 0.5 & 14.5 days \\
\hline
\end{tabular}

MOPS buffer, open to the atmosphere, and at ambient tempreature. All samples were prepared in duplicate. Blanks (i.e., without goethite) were prepared over the $\mathrm{pH}$ range 3-9 to investigate adsorption to container walls and filters, which was found to be $<3.5 \%$ of the initial DFO-B or DFO-D1 concentration. In these batch studies, $390 \mathrm{mg}$ goethite and $14 \mathrm{~g}$ electrolyte (with or without buffer) were placed in $30 \mathrm{~mL}$ amber HDPE bottles. Then DFO-B or DFO-D1 stock solution was added to give a final concentration of $150 \mu \mathrm{M}$ for the adsorption edge determination and between 10 and $150 \mu \mathrm{M}$ for the adsorption isotherm measurements (Table 1). Predetermined amounts of acid or base were added to reach the desired $\mathrm{pH}$ for each sample (i.e., $\mathrm{pH} 6.6$ for the adsorption isotherm and $\mathrm{pH} 3$ to 9 for the edge measurements). The sample bottle was filled with electrolyte solution to a final mass of $30 \mathrm{~g}$ and placed on a rotary shaker for $18 \mathrm{hr}$ (DFO-B) or $50 \mathrm{~min}$ (DFO-D1) to minimize goethite dissolution. The samples were filtered using a $0.05 \mu \mathrm{M}$ syringe filter (MF-Millipore). The first $3 \mathrm{~mL}$ of the filtrate were discarded, then $10 \mathrm{~mL}$ were filtered for $\mathrm{pH}$ measurement. Finally, $10 \mathrm{~mL}$ were collected for analysis of dissolved $\mathrm{Fe}$ and ligand concentrations.

\subsection{Dissolution Kinetics}

Goethite dissolution kinetics were measured at $\mathrm{pH} 6.5$ (where proton and hydroxide effects on dissolution should be minimal and coagulation processes are negligible) in batch experiments with a solids concentration of $0.5 \mathrm{~g} / \mathrm{L}$ in $0.01 \mathrm{M} \mathrm{NaClO}_{4}$ solution. All samples contained $5 \mathrm{mM}$ MOPS $\mathrm{pH}$ buffer except for one batch experiment that was performed to verify that this buffer does not influence goethite dissolution rates. Dissolution experiments in the presence of $\mathrm{DFO}$ and $\mathrm{Pb}$ were designed to investigate the effect of adsorbed $\mathrm{Pb}$ on dissolution. In each experiment, goethite was suspended in electrolyte solution by ultrasonification for $1 \mathrm{~min}$. Then DFO-B (or DFO-D1) and Pb stock solutions were added (Table 1) and $\mathrm{pH}$ was adjusted to 6.5 with $0.1 \mathrm{M}$
$\mathrm{NaOH}$. Finally, electrolyte was added to make a final sample mass of $200 \mathrm{~g}$. The samples then were continuously mixed on a horizontal shaker. Aliquots were taken over time and filtered with $0.05 \mu \mathrm{m}$ syringe filters (MF-Millipore). The filtrate was acidified to approximately $\mathrm{pH} 1$ with concentrated perchloric acid and stored in a refrigerator for no more than $1 \mathrm{wk}$ prior to chemical analysis.

\subsection{Data Treatment}

Lead speciation in the presence of DFO-B was calculated using the chemical equilibrium model PHREEQC (Parkhurst, 1995). Thermodynamic constants used in the calculations were taken from the literature (Table 2). Since the $\mathrm{Pb}$ adsorption experiments were open to the atmosphere, the stability of $\mathrm{Pb}$ hydroxides and carbonates were calculated, and it was ascertained that all such solid phases were undersaturated under the experimental conditions of our study.

\section{RESULTS}

\subsection{Adsorption of Lead}

In the absence of an organic ligand, $\mathrm{Pb}$ is known to adsorb strongly to goethite with increasing $\mathrm{pH}$ (Hayes and Leckie, 1986; Roe et al., 1991; Müller and Sigg, 1992; Kooner, 1993; Rodda et al., 1993; Gunneriusson et al., 1994). Figure 2 (square symbols) indicates that $\mathrm{pH}_{50} \approx 5.5$ and, at $\mathrm{pH}>7$, all $\mathrm{Pb}$ added is adsorbed. This result is consistent with previous observations of $\mathrm{Pb}$ adsorption, in the presence of a variety of background electrolytes at various initial $\mathrm{Pb}$ concentrations and solid concentrations. Both DFO-B and DFO-D1 similarly influence the adsorption of $\mathrm{Pb}$ above $\mathrm{pH}_{50}$ (Fig. 2). In the presence of

Table 2. Conditional formation constants $\left(\mathrm{K}_{\mathrm{c}}\right)$ included in the model calculatons. All constants are corrected to $\mathrm{I}=0.01 \mathrm{M}$.

\begin{tabular}{|c|c|c|c|}
\hline Reaction & $\log \mathrm{K}_{\mathrm{c}}$ & Reaction & $\log \mathrm{K}_{\mathrm{c}}$ \\
\hline $\mathrm{DFO}^{3-}+\mathrm{H} \Leftrightarrow \mathrm{HDFO}^{2-}$ & $10.46^{\mathrm{a}}$ & $\mathrm{Pb}^{2+}+\mathrm{OH}^{-}+\mathrm{CO}_{3}^{2-} \Leftrightarrow \mathrm{PbOH}\left(\mathrm{CO}_{3}\right)^{-}$ & $10.70^{\mathrm{a}}$ \\
\hline $\mathrm{HDFO}^{2-}+\mathrm{H}^{+} \Leftrightarrow \mathrm{H}_{2} \mathrm{DFO}^{-}$ & $9.35^{\mathrm{a}}$ & $\mathrm{Pb}^{2+}+\mathrm{OH}^{-} \Leftrightarrow \mathrm{PbOH}^{+}$ & $6.58^{\mathrm{a}}$ \\
\hline $\mathrm{H}_{2} \mathrm{DFO}^{-}+\mathrm{H}^{+} \Leftrightarrow \mathrm{H}_{3} \mathrm{DFO}$ & $8.90^{\mathrm{a}}$ & $\mathrm{Pb}^{2+}+2 \mathrm{OH}^{-} \Leftrightarrow \mathrm{Pb}(\mathrm{OH})_{2(\mathrm{aq})}$ & $11.18^{\mathrm{a}}$ \\
\hline $\mathrm{H}_{3} \mathrm{DFO}+\mathrm{H}^{+} \Leftrightarrow \mathrm{H}_{4} \mathrm{DFO}^{+}$ & $8.38^{\mathrm{a}}$ & $\mathrm{Pb}^{2+}+3 \mathrm{OH}^{-} \Leftrightarrow \mathrm{Pb}(\mathrm{OH})_{3}^{-}$ & $14.23^{\mathrm{a}}$ \\
\hline $\mathrm{Pb}^{2+}+\mathrm{HDFO}^{2-} \Leftrightarrow \mathrm{PbHDFO}$ & $9.48^{b}$ & $2 \mathrm{~Pb}^{2+}+\mathrm{OH}^{-} \Leftrightarrow \mathrm{Pb}_{2} \mathrm{OH}^{3+}$ & $7.61^{\mathrm{a}}$ \\
\hline $\mathrm{Pb}^{2+}+\mathrm{H}_{2} \mathrm{DFO}-\Leftrightarrow \mathrm{PbH}_{2} \mathrm{DFO}+$ & $8.99^{\mathrm{b}}$ & $3 \mathrm{~Pb}^{2+}+4 \mathrm{OH}^{-} \Leftrightarrow \mathrm{Pb}_{3}(\mathrm{HO})_{4}^{2+}$ & $32.66^{\mathrm{a}}$ \\
\hline $\mathrm{Pb}^{2+}+\mathrm{H}_{3} \mathrm{DFO} \Leftrightarrow \mathrm{PbH}_{3} \mathrm{DFO}^{2+}$ & $5.92^{\mathrm{b}}$ & $4 \mathrm{~Pb}^{2+}+4 \mathrm{OH}^{-} \Leftrightarrow \mathrm{Pb}_{4}(\mathrm{HO})_{4}^{4+}$ & $36.20^{\mathrm{a}}$ \\
\hline $2 \mathrm{~Pb}^{2+}+\mathrm{HDFO}^{2-} \Leftrightarrow \mathrm{Pb}_{2} \mathrm{HDFO}^{2+}$ & $15.77^{\mathrm{b}}$ & $6 \mathrm{~Pb}^{2+}+8 \mathrm{OH}^{-} \Leftrightarrow \mathrm{Pb}_{6}(\mathrm{OH})_{8}^{4+}$ & $69.16^{\mathrm{a}}$ \\
\hline $\mathrm{Pb}^{2+}+\mathrm{CO}_{3}^{2-} \Leftrightarrow \mathrm{PbCO}_{3(\mathrm{aq})}$ & $4.56^{\mathrm{a}}$ & $\mathrm{H}^{+}+\mathrm{CO}_{3}^{2-} \Leftrightarrow \mathrm{HCO}_{3}^{-}$ & $10.46^{\mathrm{a}}$ \\
\hline $\mathrm{Pb}^{2+}+2 \mathrm{CO}_{3}^{2-} \Leftrightarrow \mathrm{Pb}\left(\mathrm{CO}_{3}\right)_{2}^{2+}$ & $8.02^{\mathrm{a}}$ & $\mathrm{H}^{+}+\mathrm{HCO}_{3}^{-} \Leftrightarrow \mathrm{H}_{2} \mathrm{CO}_{3}$ & $6.402^{\mathrm{a}}$ \\
\hline $\mathrm{Pb}^{2+}+\mathrm{CO}_{3}^{2-} \Leftrightarrow \mathrm{PbCO}_{3 \text { (s, Cerrusire) }}$ & $-13.49^{\mathrm{a}}$ & & \\
\hline
\end{tabular}

\footnotetext{
${ }^{a}$ Martell et al. (19995)
}

b Hernlem et al. (1995). 


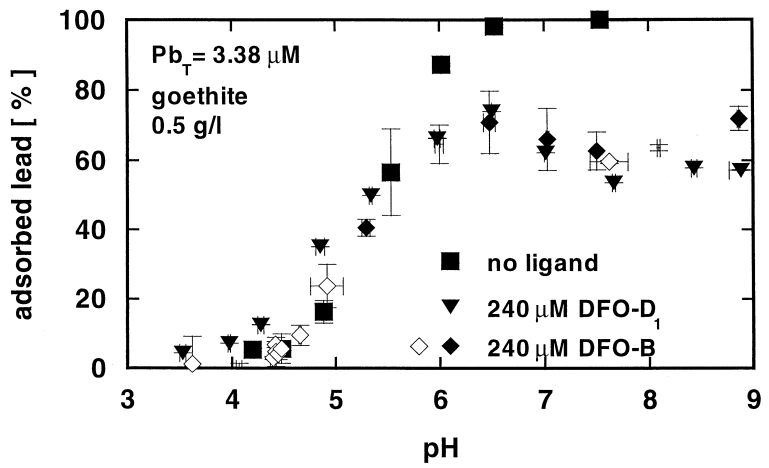

Fig. 2. Adsorption edge for $\mathrm{Pb}$ (initial conc. $3.38 \mu \mathrm{M}$ ) on goethite in the absence of siderophore, and in the presence of $240 \mu \mathrm{M}$ DFO-B or DFO-D1. Error bars indicate twice the standard deviation of duplicatesample measurements. Open diamonds are results obtained in the absence of $\mathrm{pH}$-buffer; otherwise [HEPES] $=5 \mathrm{mM}$.

$240 \mu \mathrm{M}$ siderophore, adsorbed $\mathrm{Pb}$ does not exceed $70 \%$ of the initial concentration, an effect that can be understood qualitatively by considering the competition between goethite surface sites and siderophore ligands for $\mathrm{Pb}$.

\subsection{Adsorption of DFO-B and DFO-D1}

Adsorption isotherms for DFO-B and DFO- $\mathrm{D}_{1}$ at $\mathrm{pH} 6.6$ are presented in Fig. 3. These L-type isotherms (Sposito, 1989) show maximum adsorbed siderophore concentrations of approximately 1.5 (DFO-B) and 3.5 (DFO-D1) $\mu \mathrm{mol} / \mathrm{g}$. Both of these surface concentrations are much smaller than even the lower range of previously-measured goethite surface-site concentrations (Cornell and Schwertmann, 1996). The adsorption

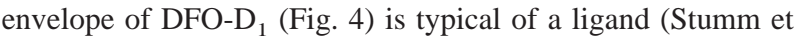
al., 1990; Stumm, 1992), with maximum adsorption being observed at $\mathrm{pH}$ 4.2. By contrast, the adsorption envelope of DFO-B (Fig. 4) is more like that of a monovalent cation (Stumm et al., 1990; Stumm, 1992), with adsorbed concentrations close to $1.5 \mu \mathrm{mol} / \mathrm{g}$ achieved at $\mathrm{pH}<7$. Above $\mathrm{pH} 7.5$, DFO-B adsorption increases to about $2.5 \mu \mathrm{mol} / \mathrm{g}$.

\subsection{Dissolution of Goethite}

Figure 5 shows data on the dissolution of goethite in the presence of DFO-B or DFO-D1 at $\mathrm{pH} 6.5$ and a total sid-

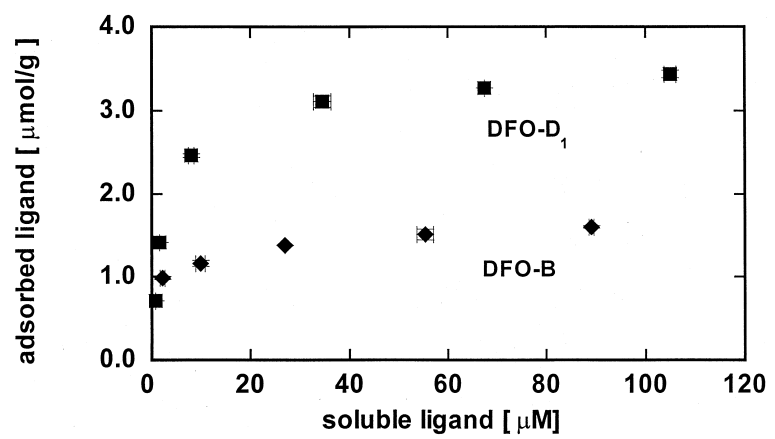

Fig. 3. Adsorption isotherms for DFO-B (diamonds) and DFO-D1 (squares) on goethite. Error bars indicate twice the standard deviation of duplicate-sample measurements: $0.01 \mathrm{M} \mathrm{NaClO}_{4}$; solid conc. 13 $\mathrm{g} / \mathrm{L} ;[\mathrm{MOPS}]=5 \mathrm{mM} ; \mathrm{pH}=6.6$.

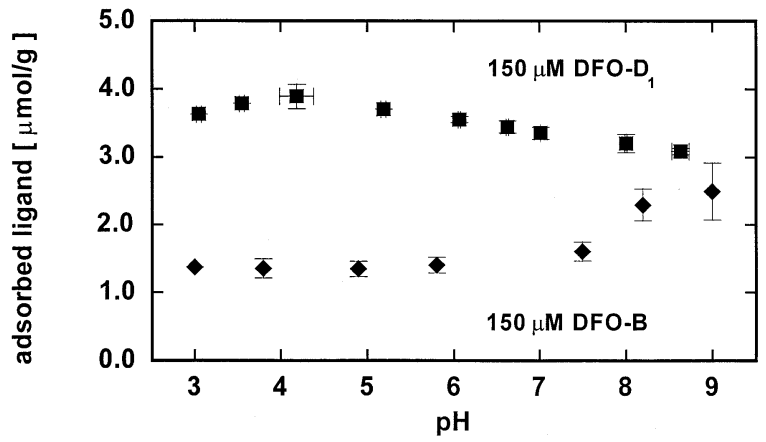

Fig. 4. Adsorption envelope for DFO-B (diamonds) and DFO-D (squares) on goethite. Error bars indicate twice the standard deviation of duplicate-sample measurements. The total ligand concentration was $150 \mu \mathrm{M}$; $0.01 \mathrm{M} \mathrm{NaClO}_{4}$; solid conc. $13 \mathrm{~g} / \mathrm{L} ;[\mathrm{MOPS}]=5 \mathrm{mM}$.

erophore concentration of $240 \mu \mathrm{M}$. After an initial fast reaction, slow dissolution with a constant rate is observed. The dissolution rate in the presence of DFO-D1 $(0.17 \mu \mathrm{mol} / \mathrm{g} \cdot \mathrm{h})$ was almost an order of magnitude higher than the dissolution rate in the presence of DFO-B $(0.02 \mu \mathrm{mol} / \mathrm{g} \cdot \mathrm{h})$. This latter result is comparable with the dissolution rate of goethite $(0.01$ $\mu \mathrm{mol} / \mathrm{g} \cdot \mathrm{h}$ ) observed by Watteau and Berthelin (1994) at a lower total DFO-B concentration of $126 \mu \mathrm{M}$. The presence of adsorbed $\mathrm{Pb}$ (total added concentrations of 3.48 and $17.4 \mu \mathrm{M}$ ) had no significant effect on dissolution in the presence of DFO-B (Fig. 5). The dissolution rate in the absence of the $\mathrm{pH}$ buffer was similar to the rate in the presence of $5 \mathrm{mM}$ MOPS, where solution $\mathrm{pH}$ drifted from 6.5 to 5.8.)

\section{DISCUSSION}

At $\mathrm{pH}>5.5$, a significant effect of DFO-B and DFO- $\mathrm{D}_{1}$ on the adsorption of $\mathrm{Pb}$ by goethite was found at the initial $\mathrm{Pb} /$ siderophore molar ratio of 0.014 used in this study (Fig. 2). It is noteworthy that, under the conditions of the present experiments, DFO-B and DFO- $\mathrm{D}_{1}$ were able to mobilize about

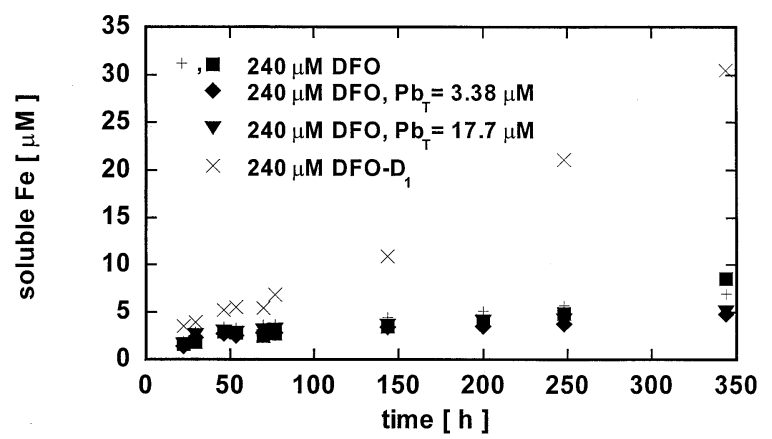

Fig. 5. Iron release by goethite in the presence of DFO- $D_{1}(X)$ or DFO-B (all other symbols). The effect of $\mathrm{Pb}$ on DFO-B-promoted dissolution was investigated by adding total $\mathrm{Pb}$ at concentrations of 3.38 or $17.7 \mu \mathrm{M}$ (diamond and triangle, respectively). The $\mathrm{pH}$ was 6.5 with a buffer concentration of $5 \mathrm{mM}$ (MOPS), except for one series of experiments $(+)$ that was performed without buffer and in which $\mathrm{pH}$ was allowed to drift from $\mathrm{pH} 6.5$ initially to 5.8 . The ligand concentration was $240 \mathrm{M}$ in all experiments; $0.01 \mathrm{M} \mathrm{NaClO}_{4}$; solid conc. 0.5 $\mathrm{g} / \mathrm{L}$. 


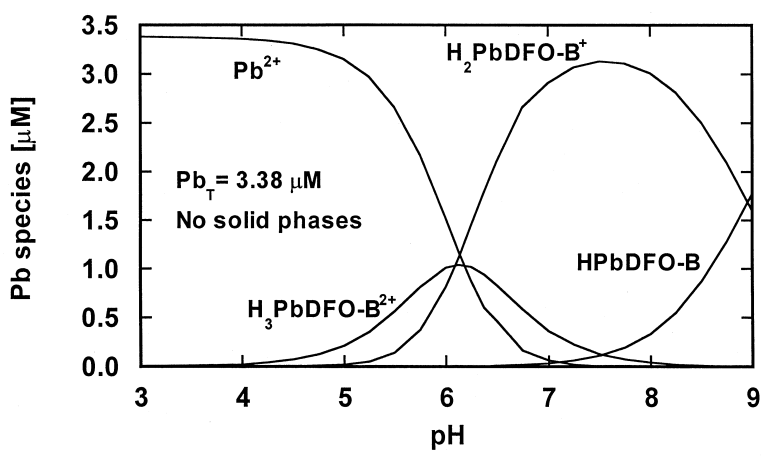

Fig. 6. Calculated speciation of $3.38 \mathrm{M} \mathrm{Pb}$ (II) in the presence of 240 M DFO-B but in the absence of solid phases (Martell et al., 1995; Hernlem et al., 1995). Note the peak for the complex $\mathrm{H}_{2} \mathrm{PbDFO}^{+}$just below $\mathrm{pH} 8$.

one-third of the $\mathrm{Pb}$ adsorbed on goethite at $\mathrm{pH}>6.5$. In the case of DFO-B, the suppression of $\mathrm{Pb}$ adsorption was greatest just below $\mathrm{pH} 8$, where the soluble complex species $\mathrm{H}_{2} \mathrm{PbDFO}^{+}$has its maximum concentration (Fig. 6). In the case of DFO-D1, the absence of any increase in $\mathrm{Pb}$ adsorption at $\mathrm{pH}>8$ could reflect the absence of positively charged soluble $\mathrm{Pb}$ species that can be attracted to the goethite surface.

The low adsorption capacity of goethite for DFO-D1 at $\mathrm{pH} 4$ (4 $\mu \mathrm{mol} / \mathrm{g}$, Fig. 4) suggests that the binding of the siderophore at the mineral surface is limited by stereochemical constraints. Under our experimental conditions ( $\mathrm{pH}$ 6.6), the maximum surface concentration of DFO-D1 is about $3.5 \mu \mathrm{mol} / \mathrm{g}$ (Fig. 3). This result can be compared directly with the surface concentration of acetohydroxamic acid (aHA) measured on goethite under comparable conditions by (Holmén and Casey, 1996), 10 $\mu \mathrm{mol} / \mathrm{g}$. Iron(III) coordination by aHA has been investigated by CIR-FTIR spectroscopy (Holmén et al., 1997), which shows that this bidentate ligand forms only mononuclear complexes both in solution and at the goethite surface. If excess ligand is present (i.e., $\mathrm{L}_{\text {diss }} / \mathrm{Fe}_{\text {diss }}>3$ ), $\mathrm{Fe}(\mathrm{aHA})_{3}$ is the dominant solution complex near neutral pH (Holmén and Casey, 1996) with a formation constant of $10^{28.3}$ (Martell et al., 1995). Compared to the dissolved tris aHA complex, $\mathrm{Fe}$ (III) complexation by DFO-B or DFO-D1 in solution exhibits only a small chelate effect, with a $\mathrm{Fe}(\mathrm{III})$ complex formation constant of $10^{31}$ (Albrecht-Gary and Crumbliss, 1998). This suggests that the three ligating groups, connected by a flexible linear organic chain (Fig. 1), coordinate Fe(III) in solution independently, in effectlike, coordination by three discrete aHA ligands. If similar behavior occurs at low surface coverage on goethite, a ratio of adsorbed DFO-D1 to aHA equal to $1 / 3$, as described above, is indeed expected under similar experimental conditions. The maximum DFO-B surface concentration, on the other hand, is less than half that of DFO-D1 (Fig. 4). Since the coordinating groups of the 2 ligands are identical, the difference in adsorption behavior must arise from a difference in molecular species charge. The positive charge on DFO-B leads to electrostatic repulsion between the ligand and the goethite surface, which is also positively charged for $\mathrm{pH}<8$. At $\mathrm{pH}>8$, electrostatic repulsion no longer exists and the adsorbed concentrations of DFO-B and DFO-D1 indeed do converge (Fig. 4).

Our goethite dissolution experiments in the presence of
DFO-B or DFO-D1 were conducted at $\mathrm{pH} 6.5$ with a total ligand concentration of $240 \mu \mathrm{M}$. The dissolution rate in the presence of DFO-D1 $(0.17 \mu \mathrm{mol} / \mathrm{g} \cdot \mathrm{h})$ is in good agreement with that reported by Holmén and Casey (1998) for goethite in the presence of aHA at a surface concentration of $10 \mu \mathrm{mol} / \mathrm{g}$ (i.e., at 3 times the DFO-D1 surface concentration), which is $0.16 \mu \mathrm{mol} / \mathrm{g} \cdot \mathrm{h}$ (Holmén and Casey, 1998). The surface concentration of DFO-D1 is about twice that of DFO-B under these conditions (Fig. 3), but the dissolution rate in the presence of DFO-D1 is more than 8 times higher than in the presence of DFO-B. Hence, the effect of these two ligands on the goethite dissolution rate is not linearly related to the adsorbed coordinating-ligand concentration.

Acknowledgments-This research was supported in part by the Director, Office of Energy Research, Office of Basic Energy Sciences, Geosciences Program, of the US Department of Energy under Grant No DE-FG03-96ER14667. Thanks to Brian Schroth for technical assistance and for insightful discussions. Gratitude is expressed to Angela Zabel for preparation of the typescript.

\section{REFERENCES}

Albrecht-Gary A.-M. and Crumbliss A. L. (1998) Coordination chemistry of siderophores: Thermodynamics and kinetics of iron chelation and release. Metal Ions Biol. Sys. 35, 239-327.

Bargar J. R., Brown G. E., and Parks G. A. (1997) Surface complexation of $\mathrm{Pb}(\mathrm{II})$ at oxide-water interfaces: II. XAFS and bond-valence determination of mononuclear $\mathrm{Pb}$ (II) sorption products and surface functional groups on oxides. Geochim. Cosmochim. Acta 61, 26392652.

Bickel H., Bosshardt R., Gaeumann E., Reusser P., Vischer E., Voser W., Wettstien A., and Zaehner H. (1960) Ueber die Isolierung und Charakterisierung der Ferrioxamine A-F, neuer Wuchsstoffe der Sideramin-Gruppe. Helv. Chim. Acta 43, 2118-2128.

Borgias B., Hugi A. D., and Raymond K. N. (1989) Isomerization and solution structures of desferrioxamine $\mathrm{B}$ complexes of $\mathrm{Al}^{3+}$ and $\mathrm{Ga}^{3+}$. Inorg. Chem. 28, 3538-3545.

Brainard J. R., Strietelmeier B. A., Smith p. H., Langston-Unkefer P. J., Barr M. E., and Ryan R. R. (1992) Actinide binding and solublization by microbial siderophores. Radiochim. Acta 58/59, 357-363.

Cornell R. M. and Schwertmann U. (1996) The Iron Oxides. VCH.

Crowley D. E. and Gries D. (1994) Modeling of iron availability in the plant rhizosphere. In Biochemistry of Metal Micronutrients in the Rhizosphere (ed. J.A. Manthey, D.E.Crowley, and D.G. Luster), pp. 199-223. CRC Press, Boca Raton, FL.

Crowley D. E., Reid C. P. P., and Szaniszlo P. J. (1987) Microbial siderophores as iron sources for plants. In Iron Transport in Animals, Plants, and Microorganisms (eds. G. Winkelmann, D. van der Helm, and J. B. Neilands), pp. 375-385. VCH Publishers, Mannheim, Germany.

Dzombak D. A. and Morel F. M. M. (1990) Surface Complexation Modeling. John Wiley.

Gunneriusson L., Lövgren L., and Sjöberg S. (1994) Complexation of $\mathrm{Pb}$ (II) at the goethite $(\alpha \mathrm{FeOOH}) /$ water interface: The influence of chloride. Geochim. Cosmochim. Acta 58, 4973-4983.

Hayes K. F. and Leckie J. O. (1986) Mechanism of lead ion adsorption at the goethite-water interface. In Geochemical Processes at Mineral Surfaces (ed. J. A. Davis and K. F. Hayes), Vol. 323, pp. 114-141. ACS symposium series.

Hernlem B. J., Vane L. M., and Sayles G. D. (1995) Stability constants for complexes of the siderophore desferrioxamine B with selected heavy metal cations. Inorg. Chim. Acta 244, 179-184.

Holmén B. A. and Casey W. H. (1996, 1998) Hydroxamate ligands, surface chemistry, and the mechanism of ligand-promoted dissolution of goethite $[-\mathrm{FeOOH}(\mathrm{s})]$. Geochim. Cosmochim. Acta 60, 44034416; Ibid. 62, 726.

Holmén B. A., Tejedor-Tejedor M. I., and Casey W. H. (1997) Hydroxamate complexes in solution and at the goethite-water interface: 
A cylindrical internal reflection Fourier transform infrared spectroscopy study. Langmuir 13, 2197-2206.

Kooner Z. S. (1993) Comparative study of adsorption behavior of copper, lead, and zinc onto goethite in aqueous systems. Environ. Geol. 21, 242-250.

Martell A. E., Smith R. M., and Motekaitis R. J. (1995) Critical Stability Constants Database. NIST., Vol. 2.

Müller A. and Sigg L. (1992) Adsorption of Lead(II) on the goethite surface: Voltammetric evaluation of surface complexation parameters. J. Colloid Interface Sci. 148, 517-532.

Parkhurst D. L. (1995) User's guide to PHREEQC-A computer program for speciation, reaction-path, advective-transport, and inverse geochemical calculations. USGS Water Resources Investigations Report 95-4227.

Powell, P. E., Szaniszlo P. J., Cline G. R., and Reid C. P. P. (1982) Hydroxamate siderophores in the iron nutrition of plants. J. Plant Nutr. 5, 653-673.

Rodda D. P., Johnson B. B., and Wells J. D. (1993) The effect of temperature and $\mathrm{pH}$ on the adsorption of copper(I), lead(II), and zinc(II) onto goethite. J. Colloid Interface Sci. 161, 57-62.

Roe A. L., Hayes K. F., Chisholm-Brause C., Brown G. E., Parks G. A., Hodgson K. O., and Leckie J. O. (1991) In situ X-ray adsorption study of lead ion surface complexes at the goethite-water interface. Langmuir 7, 367-373.

Schwertmann U. and Cornell R. M. (1991) Iron Oxides in the Laboratory. VCH Publishers.

Sposito G. (1989) The Chemistry of Soils. Oxford University Press.

Stumm W. (1992) Chemistry of the Solid-Water Interface. WileyInterscience.

Stumm W., Suzberger B., and Sinniger J. (1990) The coordination chemistry of the oxide-electrolyte interface: The dependence of surface reactivity (dissolution, redox reactions) on surface structure. Croat. Chem. Acta 63, 277-312.

Telford J. R. and Raymond K. N. (1996) Siderophores. In Comprehensive Supramolecular Chemistry (ed. J. L. Atwood, J. E. D. Davies, D. D. MacNicol, and F. Vogtle), Vol. 10, pp. 537-555. Elsevier Science.

van der Helm, D., Jalal, M. A. F., and Hossain, M. B. (1987) The crystal structures, conformations, and configurations of siderophores. In Iron Transport in Microbes, Plants and Animals (eds. G. Winkelmann, D. van der Helm, and J. B. Neilands), pp. 135-165. VCH Publishers, Mannheim, Germany.

Watteau F. and Berthelin J. (1994) Microbial dissolution of iron and aluminium from soil minerals: Efficiency and specificity of hydroxamate siderophores compared to aliphatic acids. Eur. J. Soil Biol. 30, 1-9. 